\title{
POLEDENITEV TRNOVSKEGA GOZDA
}

\section{Blaž Kodelja, Manja Žebre, Uroš Stepišnik: Po- ledenitev Trnovskega gozda. Zbirka E-GeograFF 6. Znanstvena založba Filozofske fakultete Uni- verze v Ljubljani in Oddelek za geografijo, 63 str. Ljubljana, 2013}

V zbirki elektronskih monografij E-GeograFF sta $\mathrm{V}$ letu 2013 izšli dve monografiji, od katerih nam prva prinaša rezultate najnovejših preučevanj pleistocenske poledenitve na Trnovskem gozdu. Zaradi zapletene kombinacije močno razčlenjenega krasa in razmeroma skromnih ostankov ledeniških akumulacij sta se težavne naloge v preteklosti lotila samo A. Melik (1959) in P. Habič (1968), Melikove ugotovitva pa je deloma dopolnil še geolog S. Buser (1965). Iz teh in še nekaterih prejšnjih del so bili poznani ledeniški nanosi na nekaterih lokacijah, prej omenjene rekonstrukcije pleistocenske poledenitve pa so temeljile na določitvi višine snežne meje ob višku poledenitve na nadmorski višini $1300 \mathrm{~m}$. To naj bi omogočilo nastanek ledenikov na kraških uravnavah v višinah med 700 in 1000 m na severni in južni strani slemena Golakov, na severni strani pa naj bi se manjši ledeniki prek strmega pobočja spuščali še v nižje lege v dolinah Trebuše in Idrijce ter na Hudo polje.

Skupina mlajših raziskovalcev se je lotila reinterpretacije teh starejših ugotovitev na osnovi izkušenj, ki so jih v zadnjih letih pridobili pri preučevanju pleistocenske poledenitve v drugih delih Dinarskega gorstva, ter novejših metod določanja višine ravnovesne meje ledenikov. Opravili so detajlno geomorfološko kartiranje ostankov pleistocenske poledenitve celotnega Trnovskega gozda in na osnovi tega izdelali novo karto obsega poledenitve (skupno okoli $8 \mathrm{~km}^{2}$ ledenikov), izračunali višino ravnovesne meje ledenikov ter poskušali rekonstruirati paleoklimatske značilnosti preučevanega območja.

$\mathrm{Z}$ detajlnimi terenskimi preučevanji so ugotovili, da za nekatere ugotovitve starejših raziskovalcev na terenu ni moč najti dokazov, ki bi nesporno potrjevali njihove ugotovitve. Največje razlike med starejšimi in novimi ugotovitvami so na planoti ob južnem vznožju Golakov, saj po njihovem mnenju tam sploh ni bilo ledenikov, za razliko od kar obsežnega ledenega pokrova na njihovi severni strani, ki naj bi meril 4,8 $\mathrm{km}^{2}$. To razlagajo z izoblikovanostjo površja in klimatskimi razlikami med obema stranema, zaradi katerih bi lahko bila ravnovesna meja ledenikov na prisojni strani planote več kot $150 \mathrm{~m}$ višja kot na osojni strani, kjer je bilo zaradi učinka reliefne pregrade tudi precej več padavin.

Za razliko od prisojne strani so bili po njihovih ugotovitvah na osojni strani Golakov trije ledeniki, ki so se zlili v enoten ledeni pokrov, in ne samo manjši, med seboj ločeni ledeniki v večjih kontah, kot so menili starejši raziskovalci. Na tem delu Trnovskega gozda je bilo torej veliko več ledu, kot smo mislili doslej, v Smrekovi dragi naj bi debelina ledu celo presegala $180 \mathrm{~m}$. Že starejše študije so pokazale, da so ledeniki na severni 
strani segali prek strmega pobočja še v nižje lege, vendar je nova študija podaljšala zlasti ledenik v zgornjem delu doline Trebuše, kjer naj bi skoraj 4 km dolg ledenik segal vse do nadmorske višine okoli $350 \mathrm{~m}$.

Ravnovesno mejo ledenikov so avtorji s pomočjo dveh metod (metoda deleža akumulacijskega dela ledenika in metoda zgornje meje bočnih moren) določili na nadmorski višini 1240 m, kar je 60 m nižje od nekoč določene višine snežne meje, vendar pa je zaradi temperaturne inverzije led zapolnjeval tudi kraške kotanje pod to mejo.

Paleoklimatske značilnosti Trnovskega gozda ob višku poledenitve so ugotavljali s pomočjo modela stopinjskih dni in zanj uporabili sedanje podatke o temperaturah na meteorološki postaji Vojsko (n. v. 1067 m) in podatke o padavinah na padavinski postaji Mrzla rupa (n. v. 930 m). Pri tem so upoštevali ugotovitve, da naj bi bile povprečne temperature v Sloveniji ob višku poledenitve za $7{ }^{\circ} \mathrm{C}$ nižje od današnjih, prav tako pa naj bi bilo na območju Alp in Dinarskega gorstva ob višku poledenitve, v nasprotju s starejšimi ugotovitvami, več padavin kot danes, torej so bili v tem delu Evrope pogoji za nastajanje ledenikov ugodnejši, kot se je mislilo pred dobrega pol stoletja. To med drugim pomeni, da bo potrebna ponovna preučitev in reinterpretacija dosedanjih rezultatov preučevanja ledenikov tudi v drugih delih Slovenije, za še zanesljivejšo potrditev pa bo nujno pridobiti finančna sredstva za uporabo novih metod absolutnega datiranja ostankov nekdanjih ledenikov.

Karel Natek 